\title{
Assessing the Effect of Adequate and Inadequate Inorganic Fertilizer Rates on the Yield Levels of Paprika in Mutasa Resettlement Area, Manicaland Province, Zimbabwe
}

\section{Culver Mvumi}

Ministry of Agriculture, Agritex Department, P. O. Box 146, Mutare, Zimbabwe.

ARTICLE INFO

Article No.: 011313374

DOI: 10.15580/GJAS.2013.3.011313374

Submitted: 13/01/2013

Accepted: 20/01/2013

Published: 20/03/2013

${ }^{\star}$ Corresponding Author

Culver Mvumi

E-mail: culmvi@yahoo.com

Keywords:

Paprika, adequate/ inadequate

fertilizer, rate
A survey was carried out to evaluate the effect of adequate and inadequate inorganic fertilizer rates on the yield of Paprika (Capsicum annuum var. angulosum mill) in Mutasa resettlement area, Mutasa district. Questionnaires and interviews were used to produce primary data from 42 respondents in 2009. Secondary data was obtained mainly from Agricultural Technical and Extension Services (AGRITEX) and Paprika Company of Zimbabwe. Mean yields of paprika obtained from adequate and inadequate basal and top dressing fertilisers were compared and analysed using ' $Z$ ' statistical test at 0.05 level of significance. Mean yield from inadequate fertilizer rates of $\mathbf{3 0}$ farmers was $0.8 \mathrm{t} / \mathrm{ha}$. The mean yield from adequate fertilizer rates of 12 farmers was 1.0t/ha. Results showed that the two means were significantly different. Adequate fertiliser rates produced significantly higher mean yield than the mean yield from inadequate fertiliser rates. The higher mean yield was enhanced by the highest number of (5) top dressing split applications. The study therefore recommends the use of adequate rates of $700-1000 \mathrm{~kg} / \mathrm{ha}$ basal fertilizer, $250-350 \mathrm{~kg} / \mathrm{ha}$ ammonium nitrate (AN) and $350-400 \mathrm{~kg} / \mathrm{ha}$ of potassium chloride. The top dressing has to involve 5 split applications. This exploits its high fruit yielding potential. Additional research is required to determine response of the crop, as a high value crop, to foliar and fertigation fertiliser application. 


\section{INTRODUCTION}

Paprika (Capsicum annuum L.) belongs to the Solanaceae family and is closely related to potato (Solanum tuberosum L.), tomato (Lycopersicon esculentum Mill.) and tobacco (Nicotiana tabacum L.) (Ware and McCollum, 1980). This crop belongs to the sweet pepper group from whose fruit a concentrated spice product, oleoresin is extracted and used as an ingredient in industrial food processing (Mvere, 1996). Paprika is generally used as a culinary colouring agent, as a flavouring vegetable or as a seasoning in cooking, in cheese, in processed meats, in goulash or eaten raw in salads (Peirce, 1987). It is now widely used to replace artificial food colourants that are believed to be carcinogenic in humans (Paprika Zimbabwe, 2000).

Paprika, an important high value cash crop, has the potential to boost Zimbabwe's foreign exchange earnings since the entire production is exported, specifically to Europe. Its production will also improve the livelihood of the smallholder $(\mathrm{SH})$ farmers through increased incomes. The production of paprika in Zimbabwe is relatively recent and major production dates back to 1992 (Agrikor, 2000). Zimbabwe has been the largest producer of paprika in Southern Africa since 1997, and has in fact replaced Morocco as the largest African supplier of raw materials to international markets (Agrikor, 2000).

The sudden changes in the Zimbabwe agricultural system necessitated by the Land Reform Programme have caused sporadic fluctuations in crop production, forcing the nation to grow various types of crops (Hoogeveen and Kinsey, 2001). This was an effort to achieve food self sufficiency and better incomes. Mutasa South farmers have tried crops like common beans (Phaselous vulgaris L.), Paprika (Capsicum annum L.) and tomato (Lycopersicon esculentum L.). As a high value cash crop and income generator, some communal farmers have ventured into growing paprika. This means paprika guarantees communal farmers a reliable income. The produce is exported and there is a ready market created by companies such as Hyveld Seed, Paprika Zimbabwe and others.

Although paprika production in the smallholderfarming sector in Zimbabwe is fast gaining momentum, it has so far received very little research attention. Research on paprika has been done for the commercial sector by private individuals and companies and their results are confidential, thus not made available to the general public, which may otherwise make use of such vital information. This has greatly limited the availability of, and access to information by $\mathrm{SH}$ farmers. Also, the high input recommendations being given to $\mathrm{SH}$ farmers by both extension and paprika contracting companies are specific for commercial producers, who have precision equipment and heavy capital outlays at their disposal.

Mutasa South is a communal resettlement area in Manicaland province, Zimbabwe. This part of Zimbabwe is in farming region $2 \mathrm{~b}$ and 3 . Pockets of agro ecological zones 1-4 are dotted in the district.
Farmers in this area face problems like limited access to fertilizers, inadequate transport to ferry their produce to markets in urban centres, lack of pricing policies and absence of government intervention in paprika production has given rise to limited access to high - priced markets in Zimbabwe. There is no access to direct export markets which offer higher prices for smallholder paprika growers. There is lack of technical back-up to most smallholder farmers from research and extension service providers.

The major constraint in communal resettlement areas is of fertilizers. For example, farmers are recommended to use basal fertilizer rates of $700-1000$ $\mathrm{kg} / \mathrm{ha}, 250$ - $350 \mathrm{~kg} / \mathrm{ha}$ AN and $350-400 \mathrm{~kg} / \mathrm{ha}$ of potassium chloride (Ministry of Agriculture Mechanisation and Irrigation Development, 2010; Agricultural Technical and Extension Services, 2000; Agrikor, 2000). The AN rate/ha is applied in five split applications in order to optimize its yield potential (Ministry of Agriculture Mechanisation and Irrigation Development, 2010). The majority of communal farmers cannot afford these high fertilizer rates (Agrikor, 2000). Farmers have indicated difficulty in sourcing the recommended compound "L". This is because agrodealers do not supply it, mainly because farming in communal resettlement areas is maize based and the fertilizer used for maize is compound " $D$ ". Consequently, farmers use the readily available fertilisers for maize such as compound "D" and ammonium nitrate (AN) as well as manure to grow paprika. However, the response of paprika to these types of fertilisers has not been reported. Compound " $L$ " is recommended for paprika because it contains boron which enhances fruit formation and has fairly high $\mathrm{P}_{25}$ (17\%) which ensures availability of phosphorus throughout the long growing season required for paprika (about seven months).

Optimum yields in paprika production can be obtained when the right inputs and recommended rates especially inorganic fertilizers, are used (Mawengahama et al., 2003). Recommended fertilizer rates for a given crop are therefore important tools in agriculture to enhance high yields. Most of the research on paprika in the country lacks enough literature on paprika yield levels as there are doubts that resettlement farmers in Zimbabwe use recommended rates of fertilizer to optimize the yields. Apparently, the recommended rates and amount of inorganic fertilizers needed for optimum paprika are not known in Mutasa South resettlement area, and therefore, not followed.

The objective of the current study is to find how paprika yield responds to adequate and inadequate rates of inorganic fertilizers used in Mutasa South resettlement area, Mutasa District, in Manicaland Province.

The hypothesis of this research is:

$\left(\mathrm{H}_{0}\right)$ There is no difference in mean yield levels obtained from use of adequate fertilizer rates and from inadequate fertilizer rates. 
Or $\mathrm{X}_{1}=\mathrm{X}_{2}$

$\mathrm{H}_{1}$ : $\quad$ Mean yield from use of adequate fertilizer rates is bigger than mean yield from inadequate fertilizer rates.

Or $\mathrm{X}_{1}<\mathrm{X}_{2}$

\section{RESEARCH METHODOLOGY}

\section{Research site}

The survey was carried out in Mutasa resettlement area in Mutasa District (Manicaland Province). Soil tests were done at Soil Science Laboratory of Africa University, a university in Mutare, in Manicaland Province. The soil ranges from sandy loam to clay loam and $\mathrm{pH}$ range is $6.5-7.2$.

\section{Data collection}

\section{Primary data}

The data was collected through observation and direct measurements in the study area. Questionnaire interviews helped in collection of data on production, which included area of land under cultivation, crop distribution, labour and inputs used in producing the crop.

\section{Secondary data}

Secondary data was obtained from both AGRITEX headquarters and district offices. Yields of paprika per season, extension and support services details were also provided through secondary data.

\section{Selection of respondents (sample)}

Hansen (1953) defines a sample as a subject of the population selected to obtain information concerning the characteristics of the population. A sample is economic and easy to manage.

The respondents were selected using a stratified random sampling technique for the villages in Mutasa South resettlement area. This technique divided the study population into mutually exclusive homogenous subpopulations (Poate and Daplyn, 1993). Each village, with the help of the AGRITEX officer of Mutasa District, had some representative farmers who were chosen in proportion to its size in the sample.

The AGRITEX officer provided all the names of the farming households in the 7 villages in the area of the study and the samples were drawn from the supplied names. There were two samples taken. Sample 1 had 30 farmers while sample 2 had 12. A total of 42 households were sampled and interviewed out of the 7 villages that served as the research study area.

\section{Interview}

The study used structured questionnaires administered to households for collection of data. The targeted member was the household head growing the crop. The questionnaire collected from household information, which included age, sex of household head and occupation of the household head. Crop production details, knowledge dissemination channels, extension, training and marketing information were also collected through using a questionnaire. It also captured perceptions and sentiments of farmers on the crop.

\section{Data analysis}

The raw data captured from quantitative approach was used. The ' $Z$ ' distribution was used to statistically find if there was difference in the mean levels and then analysed the mean yield levels from adequate fertilizer rates and from inadequate fertilizer rates.

\section{RESULTS}

In this study, the analysis and results are based on the survey data collected for the $2009 / 2010$ production season.

Yield levels from inadequate fertilizer rates of 30 farmers were recorded and a mean of $0.8 \mathrm{t} / \mathrm{ha}$ was obtained. The variance was 0.30 . Yield levels from adequate fertilizer rates of 12 farmers had a mean of 1.0t/ha and the variance was 0.50 (Table 4.1).

Table 4.1:Means/averages and variances of yield levels of paprika sampled in Mutasa District

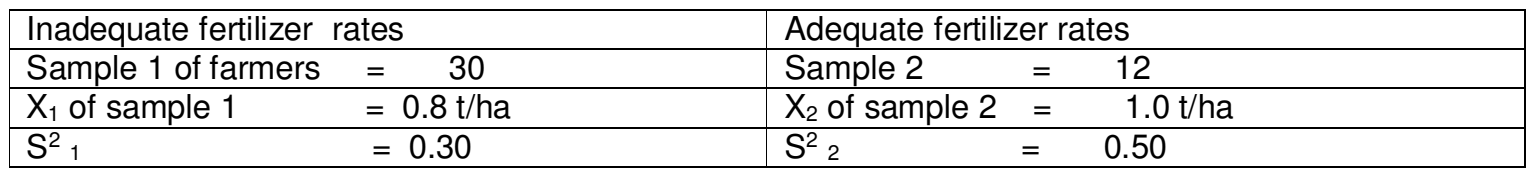

\section{Where: \\ $\mathrm{X}=$ Mean/average \\ $\mathrm{S}^{2} \quad=\quad$ Variance}

However, a statistical analysis to determine the difference between the mean yields $X_{1}$ and $X_{2}$ was done using ' $Z$ ' statistic, two tail tests. Below is the ' $Z$ ' statistic test procedure for comparison of mean yields $X_{1}$ and $X_{2}$. 


\section{'Z' statistics procedure}

i. $\mathrm{H}_{0} \quad$ : $\quad$ No difference between $X_{1}$ and $X_{2}$

ii. $\mathrm{H}_{1} \quad: \quad \mathrm{X}_{2}$ Bigger than $\mathrm{X}_{2} \ldots \ldots \ldots$ Two tail test
iii. $\mathrm{Z}_{\text {stat }}$

$Z=X_{1}-X_{2}$

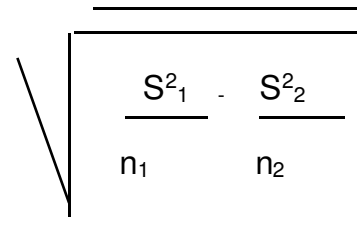

$\mathrm{Z}=$
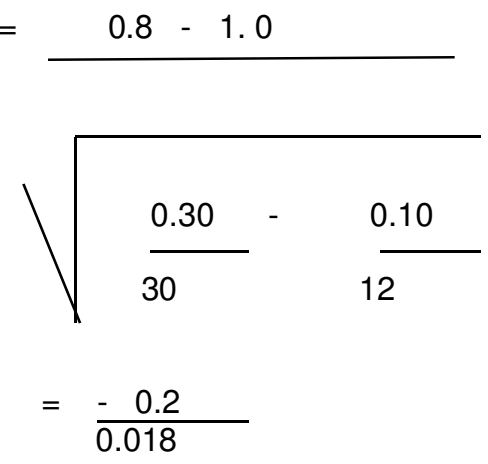

$=-1.481\left(Z_{\mathrm{tab}}=1.96\right)$

\section{DISCUSSION}

Results of the survey showed that sample 1 had 30 farmers who used inadequate rates of inorganic fertilizers, while sample had only 12 who used adequate rates. These results agree with Agriko (2000), who mention that majority of communal farmers cannot afford high fertilizer rates of paprika. Farmers have indicated difficulty in sourcing the recommended compound " $\mathrm{L}$ " which is the recommended compound fertilizer for paprika. The mean yield of sample 1 (farmers who used inadequate fertilizer rates) was $0,8 \mathrm{t} / \mathrm{ha}$ and the mean yield of sample 2 (farmers who used adequate rates) was 1.0t/ha (Table 4.1). This outcome showed that the number of farmers had no influence on yield. The statistically proved difference of the mean yields was therefore mainly due to adequacy and inadequacy use of inorganic fertilizer. However 1.42 from the ' $Z$ ' statistic shows a small difference. The was because the farmers who used inadequate rates had some of them who used rates which were a little below $700 \mathrm{~kg} / \mathrm{ha}$ and $250 \mathrm{~kg} / \mathrm{ha}$ of compound $\mathrm{L}$ and $A N$ fertilizers respectively. It was also observed that some of these farmers would only manage 4 top dressing split applications after using $700 \mathrm{~kg} / \mathrm{ha}$ compound $D$ instead of $L$. These variations contributed to the difference in the mean yields of paprika yields obtained from areas where adequate and inadequate fertiklizer rates were used.

\section{CONCLUSION AND RECOMMENDATION}

The study proved the need to use recommended rates in paprika production so as to exploit the high potential of the crop in Mutasa District. The study also revealed that paprika is a heavy feeder which can only optimize its yield potential when properly fertilized (Agrikor, 2000). These findings agree with (Ministry of Agriculture Mechanisation and Irrigation Development, 2010) which also highlighted this and gave specific recommendations of basal fertilizer rates of $700-1000$ $\mathrm{kg} / \mathrm{ha}, 200-300 \mathrm{~kg} / \mathrm{ha}$ AN and $350-400 \mathrm{~kg} / \mathrm{ha}$ of potassium chloride with 5 split applications of AN. The high number of split applications of AN fertilizer reduces leaching of nitrogen and avails as much of it as possible to the crop.

The study recommends use of adequate amounts of both basal dressing and top dressing fertilizers in order to optimize the yielding potential of paprika.

\section{ACKNOWLEDGEMENTS}

I am grateful to B.S.B. Madondo, for his editing skills. The confidence he showed in me was great. To him, I am also grateful for his clear interest in paprika. He gave all the advice and support needed, hence making me sail through.

A final word of thanks goes to the extension staff whom I worked with for their support. I also pass 
my sincere gratitude to all the farmers who participated during my project work in Mutasa South resettlement area, Mutasa District.

\section{REFERENCES}

Agrikor SA (2000). (PTY) LTD. Paprika. Updates and Latest News. 6pp.

Aliyu L (2000). Effect of organic and mineral fertilizer on growth, yield and composition of pepper (Capsicum annuum L.). Biological Agriculture and Horticulture. 18: $29-36$.

Agricultural Technical and Extension Services (2000). Paprika. Ministry of Agriculture and Rural Resettlement, Harare, Zimbabwe. 7pp.

Hansen MH (1953). Sample Survey Methods and Theory. Wiley Publications. New York.

Hoogeveen H and Kinsey B (2001). Land reform, growth and equity: Emerging evidence from Zimbabwe's resettlement programme: A sequel. Amsterdam. Journal of Southern African Economics. 27(1): 127-136.
Johnson DC and Decoteau DR (1996). Nitrogen and potassium fertility affects jalapeno pepper plant growth, fruit yield, and pungency. HortScience. 31 (7): 1119-11.

Mavengahama S, Ogunlela VB and Mariga DIK (2003). Response of Paprika. (Capsicum anuum L.) to different basal fertilizers. Department of Crop Science. UZ Zimbabwe.

Ministry of Agriculture, Mechanisation and Irrigation Department, Zimbabwe (2010). Farm Handbook. Field Crops. Vol. 1

Mvere B (1996). Cultivating paprika. Farming World. 22 (11): 13-15.

Paprika Zimbabwe (Pvt) Ltd (2000). Paprika handbook. $11 \mathrm{pp}$.

Peirce LC (1987). Vegetables - Characteristics, Production and Marketing. John Wiley and Sons. New York. pp 325 - 329.

Poate CD and Daplyn PF (1993). Data for Agrarian Development. Cambridge: London.

Ware GW and McCollum JP (1980). Producing Vegetable Crops. 3rd ed. The Interstate Printers and Publishers Inc. Danville, Illinois. pp 391 - 402.

Cite this Article: Culver Mvumi (2013). Assessing the Effect of Adequate and Inadequate Inorganic Fertilizer Rates on the Yield Levels of Paprika in Mutasa Resettlement Area, Manicaland Province, Zimbabwe. Greener Journal of Agricultural Sciences, 3(3): 199-203, http://doi.org/10.15580/GJAS.2013.3.011313374. 